International Journal of Economics, Business and Accounting Research (IJEBAR)

Peer Reviewed - International Journal

Vol-5, Issue-1, 2021 (IJEBAR)

E-ISSN: 2614-1280 P-ISSN 2622-4771

http://jurnal.stie-aas.ac.id/index.php/IJEBAR

\title{
THE EFFECTIVENESS OF SUCCESSION IN A FAMILY BUSINESS: CASE STUDY ON BATIK INDUSTRY IN INDONESIA
}

\author{
Istiatin, ${ }^{1)}$ Ari Susanti ${ }^{2)}$ \\ ${ }^{1)}$ Islam Batik University of Surakarta, Indonesia \\ ${ }^{2}$ Sekolah Tinggi Ilmu Ekonomi Surakarta, Indonesia \\ Email : istiatinumi@gmail.com
}

Abstract : The purpose of this study is; To describe succession planning and an effective succession model, to create a successful successor, to describe the planning and design an effective succession model, and to create a successful successor in both PT. Danliris and Batik Semar. The method used in this study is qualitative descriptive. Data collection is by observation and using in-depth interviews. Informant selection was determined by purposive sampling. The validity of the data was tested by the source triangulation. The results show that PT. Danliris has been succesfully done the succession because the founder involved the successor. Although the delivery of the succession was unplanned, the mentoring process went naturally and create the third generation as the successor who has good responsibility for the sustainability of the family business. In the other hand, PT. Batik Semar did not perform succession effectively because the founder did not involve the successor. The founder still in charge in family business' operations. The third Generation of Batik Semar is currently still leading and the successor just become passive leader. And up to now, the decision makers are still done by the founder.

Keywords; Family Business, succession planning, effective succession model, qualified successor.

\section{Introduction}

The succession of a leadership is one of the most significant things in the privately-owned company. Succession is very essential to ensure the sustainability of a business that is owned by family [28]. The founders of a family business try to ensure that the control of the family keep continues through intergenerational switching [21]. One of the factors that drives the success of family business is by making the succession plan [15]. In reality, many family businesses fail to make succession plan [20]. Many family businesses are not able to give the stick of leadership to the next generation. In 2014, the Family business institute found that there were just $30 \%$ of successful family businesses run by their second generation and just $12 \%$ of successful businesses regenerate in the third generation. Failure occurs due to mismanagement, incompetent or unprepared successors, and competition within the family [21].

This study aim to explain succession planning and find an effective model of succession for creating successor in PT. Danliris and PT. Batik Semar. The research questions in this study are:

Q1. What is the planning process, the succession model, the mentoring, and the skills that the successor must possess? 
E-ISSN: 2614-1280 P-ISSN 2622-4771

http://jurnal.stie-aas.ac.id/index.php/IJEBAR

\section{Literature Review}

\section{Family Business}

The concept of family business has been widely adopted in many countries and the number of family businesses is increasing [31]. When starting a business, the entrepreneur is often the sole owner and business manager. Over time, he transfers some of their ownership and / or their decision rights to more people - sometimes to the family members and sometimes to someone who doesn't (Bennedsen et al. 2015). [13] view the family business in the context of decision-making and leadership control. [9] defines a family business as one in which ownership and policy-making are dominated by family members who have emotional attachment.

\section{Founder's Role in Succession Planning}

Succession planning by founders in family business is crucial to success. The success and the continuity of the family business depend on the ability of the owner or founder of the business to start planning succession early in the business life [1]. Succession as a major determinant of generation continuity involves families compare to external employees [27]. The Success of the family business succession will greatly impact on the corporate continuity [28]. All family members must be involved and contribute to the success of leadership succession in the next generation.

Succession of succession in the family business is determined by many factors. The founder should avoid nepotism in the choice of substitute [1]. A succession plan must reflect a true management succession. The problem also occurs when the founder chooses the youngest child or the female sex (Barnes 1988). The next problem occurs due to the absence of well-structured planning. In a study that was conducted [30] explains that the succession of Chinese restaurant business family is more successful than the Indonesian restaurant. It happens because the Chinese restaurants have more structured planning than the Indonesian family restaurant business.

The succession process of the family business is a multi-stage and time process which begin before the inheritors enter the business [16], and this is noticed by the increasing involvement of initiators in business. [26] explains that there are several founding roles in business succession, those are The pre-succession process is the process by which the founder will prepare his successor. The process of succession occurs when the founder gives the family business leadership to his successor. The post-succession process is a process whereby the founder will not interfere again in the course of the family business.

\section{Mentoring Stages}

In preparing the next generation, the founders must provide mentoring or sufficient level of education. Successors should be well-prepared and get a variety of training, one of them is highly determined by the mentoring process [18]. The Founder must provide an opportunity to the future generations to have sufficient education and sufficient experience in order be ready to become leaders in the future. The Founder must endeavor to transfer the knowledge that he or she has to prepare the next generation[7]. There are four ways of mentoring, those are formal education, leadership development, developing the corporate strategy, and evaluating the performance. 
International Journal of Economics, Business and Accounting Research (IJEBAR)

Peer Reviewed - International Journal

Vol-5, Issue-1, 2021 (IJEBAR)

E-ISSN: 2614-1280 P-ISSN 2622-4771

http://jurnal.stie-aas.ac.id/index.php/IJEBAR

\section{Good Succession Model}

Succession planning is supposed to be a systematic and deliberate exertion of assuring the sustainability of the family business, to develop and make due later on [25]. The succession planning must be joined by a solid administration. The process must be well planned from the beginning. Succession must be through a decent arranging as it will enormously influence the sustainability of the family business [2]. The fruitful succession includes every relationship to different and in addition correspondence between occupant, successor, Family, [4]. As indicated by [5] powerful succession demonstrate comprises of four parts, those are Identity framework, Family System, Ownership System and Management System. Researchers will review to how much creators' employments, levels and instances of mentoring, the succession demonstrate associated and the third successor qualities

\section{Successor Characteristics}

created[24] explains how successors must have the right skills in order to be able to continue family business leadership. These skills include: Business Skill, Self-understanding, fully responsibilities successor, to lead \& to serve. Having a good relationship both to the family or nonfamily, ability to synergize, ability to empower, being respected by the employees, suppliers, costumer, and family members, competence in accordance to the strategic needs, giving respect to the past and giving the focus to the future of the family business.

\section{Research Method}

This kind of this examination utilizes a subjective methodology. Subjective research delivers and procedures elucidating information. This investigation was directed for a year. The systems of information gathering will be done before the meeting with informant so as to comprehend the genuine states of both privately-owned company and it is additionally turned into the underlying data for specialists. At that point the following activity is doing inside and out meetings with individuals who are delegated as sources by direct meeting and furnished with a recording device. Specialists will burrow information through the Directors, the bad habit Director, and delegates who have worked in PT. Danliris and PT. Batik Semar, for no under 30 years working knowledge. Meeting is additionally finished with successors, to know the inspiration they claimed, the spirit of business they have and their enthusiasm for proceeding with the business The analyst will at that point play out the technique for documentation contemplate. In this progression the specialist will gather different documentations from the organization those are the data that has been distributed in different media, both printed and electronic. The analyst likewise takes pictures or photos as per the necessities of the examination. The information acquired will be tried its legitimacy utilizing Triangulation technique with the expectation to analyze the after effects of meetings from a few witnesses to get legitimate data. The sources met at Danliris organization are (1) Mr. Marino with his $41^{\text {st }}$ years working experience, (2) Pak Yohanes is at his $43^{\text {rd }}$ years, (3) Bu Ninuk is at her $39^{\text {th }}$ years Medium Informan Batik Semar company is (1). Ibu Ninik Kasigit (founder). 2) Mr. Agus at his $37^{\text {th }}$ years (3). Mr. Joko is at his $30^{\text {th }}$ years. 
International Journal of Economics, Business and Accounting Research (IJEBAR)

Peer Reviewed - International Journal

Vol-5, Issue-1, 2021 (IJEBAR)

E-ISSN: 2614-1280 P-ISSN 2622-4771

http://jurnal.stie-aas.ac.id/index.php/IJEBAR

\section{Results and Discussion}

The description of the ${ }^{\text {results }}$ of this study can be seen in Appendix 1. There are four important points discussed in this research, namely: The role of the founder in succession process, the mentoring stage, the effective succession model, and the successor characteristics.

\section{a. Analysis of Founder's Role / Succession Planning in PT. Danliris and PT. Batik Semar}

Pre succession

Pak Tjokro as the founder of PT. Danliris has arranged his kids for formal training in to the school [8]. It turns out to participate forming the character of his children in order to have motivation to continue the business in the future. According to the informant number 1,2, and 3, the candidate of successor has the desire to pursue formal education even in abroad. This activity was done in order to prepare the strong will in continuing to run the business and to keep it sustain [24].

Succession Process.

Casual preparing education, as indicated by witness number 1 and 3, the hopeful of the successor had frequently been conveyed by his dad to the production line since the successor was in grade school. The goal of this action was that the kids would notice and know crafted by his dad and his dad's working environment. Visits or solicitations to go to the processing plant notwithstanding draw nearer and be progressively acquainted with the back to front of his dad's activity is additionally a longing to develop enthusiasm of his kids to have a feeling of proprietorship to the company. At that point later on, when the hopeful of this successor is truly turned into a successor, will be required to be a not too bad successor and prepared to carry succession and sustainability for the exclusive family business.

Having the experience of working outside of the privately-run company is vital to be actualized in the company. By having that encounter, successor will learn numerous things that are useful when successor later turned into the creator that most in control in the privately-run company [5]. Having the experience of working outside of the privately-run company will expand information and rearrange assignments to do, in order to make an additional incentive to the successor. The learning will be use by the successor to manage and build up the family business to keep the family business sustainability.

Post Succession

As indicated by informant number 1 and 3 from PT. Danliris, post-succession had done all of a sudden trough outside of the arrangement due to Pak. Handiman, the son of the founder, passed on. This condition affected the distinction in the expert or progression in the secretly privately-family business to be done abruptly. That was the reason a third-age that was relied on to be the substitute was depended upon to rapidly lead the covertly secretly privately-owned company. Luckily, the young woman of Pak. Handiman named Michelle Tjokrosaputro who beginning late continued ahead from International Business Administration and International Communication at The American University of Paris, France, can be trusted to hold and lead the family affiliation starting in the no so distant past until 2017. 
International Journal of Economics, Business and Accounting Research (IJEBAR)

Peer Reviewed - International Journal

Vol-5, Issue-1, 2021 (IJEBAR)

E-ISSN: 2614-1280 P-ISSN 2622-4771

http://jurnal.stie-aas.ac.id/index.php/IJEBAR

\section{b. The Founding Role Examination in PT.Batik Semar}

Pre-Succession, Succession and Post Succession

As indicated by Informants number 1, 2, 3 and 4, the founder whose name is Ibu Ninik Kasigit, Batik Semar company is a family business oversaw predominantly by the main family with no job of expert. Bu Ninik Kasigit did not make arrangements for succession on the grounds that as of recently the leader of Batik Semar company is as yet held by the Founder, Ibu Ninik Kasigit closedly as the second era. Batik Semar company, at that point likewise driven by the third successor, Arie Kasigit. In any case, the main action and the basic leadership still stays by Ibu Kasigit as the founder and proprietor

\section{c. Examination of Mentoring Process at Danliris company}

The coaching strategy at Danliris organization is done by outsiders of the family who have experiences in data and position inside the organization with the objective that they focus to seek after their understanding. As demonstrated by Informants number 1, 2, and 3, Successor has built up his comprehension from the formal enlightening that they have done and they beginning at now have a sufficient planning in Bachelor measurement of Business Administration. The coaching strategy is done ordinarily. That is by technique for mentoring of all pieces of power that are required in regards to utilization of the control of the Family Business. As demonstrated by Informants number 1,2, and 3 , successors lead well and overflowing with obligation and gravitate toward to all laborers from various measurements.

The correspondence that exists among tutor and mentee is cozy and close. It helps the way toward tutoring. The aftereffect of the coaching turns out to be quicker felt that is, the development of successors in maintaining the privately-run company further developed and it is relied upon to keep up sustainability of the privately-run company. This great relationship, between the guide and the mentee, makes the portion and detachment closer.

Successors have works obligation with high accomplishments and high rewards also. As per source number 1,2, and 3, successors who have programs dependably apply working evaluation and reparation in the organization to continue making and doing combating. Updates are made dependably so as to allude to improvement the affiliation's execution and early, is to accomplish transcendence in battling. As shown by Informants number 1,2 and 3, after the tutoring stage is passed, by then the instance of preparing through the successor lift is to enter from the base position and rise rapidly with the target that the association win beginning in the no so far off past.

\section{Investigation of Mentoring Process at Batik Semar Company}

As indicated by the informant Batik Semar number 1,2 and 3, the founders to the third successor that there was no thought related to training, what has been running in Batik Semar everything like modified bicycle continued running without any other individual, there is no execution evaluation. The company is done solidly just by family. The delegates simply understand that they have to work and get paid. The achievement of the company did not show any progression in light of the fact that there were no methods for mentoring process. 
International Journal of Economics, Business and Accounting Research (IJEBAR)

Peer Reviewed - International Journal

Vol-5, Issue-1, 2021 (IJEBAR)

E-ISSN: 2614-1280 P-ISSN 2622-4771

http://jurnal.stie-aas.ac.id/index.php/IJEBAR

\section{Compelling Succession Analysis Model at Danliris company and Batik Semar company}

As per [5], there are four Effective developments in Family business. Those are; Personality System, Family System, Ownership structure and Management framework. As indicated by Informant number 1,2, and 3 of Danliris association, about the character structure, demonstrates that successor has edifying foundation of Business Administration and religious rationale. It makes them common to scan for information and experience from outside and in addition in organization Successors additionally offer intending to the specialist about action.

Successors additionally have high affability and high trust in maintaining family esteems and grasp forerunner initiative culture. Identified with the Family framework as indicated by Informant number 1, 2, and 3 Successor, Michelle Tjokro Saputro profoundly comprehends to the way of life of her family by handing it over the business in a prime position for the prevail of the company as the objectives. Successors increment the estimation of resources for keep family solidarity and keep the desire for a superior accomplishment than their forerunners. Besides, about the Management System of Informants, Informants number 1,2, and 3 expressed that all administration is done straightforwardly and justly by applying the forerunner's responsibility, those are; that originator, the pioneer and the worker may kick the bucket however Danliris company must stay alive and solid, subsequently successor 3 actualizes the framework Open administration and majority rule initiative to achieve the objective and Danliris keep support by keeping up the family's lifestyle and the successor is facilitated to the interests of works execution and pleasant associations.

Powerful Succession Model Analysis at Batik Semar organization.

As indicated by Semar Batik informants, source number 1 communicated that Batik Semar did not do the progression procedure it was done just by pointing somebody. The third Successor (that was pointed by Ibu Kasigit) has a formal Bachelor's ability in any case reality the one that was pointed don't anticipate the Science of business and has no relationship in Business Practice since he was barred since the start and has no vitality and necessities inspiration.

As shown by Informant number 3, successor has needs sureness and has needs incredible relationship with the laborers. The circumstance of successor is similarly as an operational specialist. While the subsequent period is holding the organization 's cash related. Each and every fundamental development are held by the originator (first generationl) and his young lady (Bu Nanik) as the subsequent period and successor as the third time of the operational portion (operator). Batik Semar organization is a secretly run organization that has neither done the change nor professionalization yet. The organization is done closedly by the Founder.

\section{d. Examination of Successor Characteristics Generated At PT. Danliris}

The Informants of Danliris organization (number 1, 2, and 3) express that the third successors, Michelle Tjokro saputro have excellent limit especially in managing the accomplishment of the organization. He has an OK relationship and gravitate toward to anyone. He can synergize and draw in the laborers. He is incredibly respected by anyone. Michelle is a pioneer who suits the necessities of Danliris, in light of the way that he regards his forerunner and spotlights on the energy of making Danliris later on. 
International Journal of Economics, Business and Accounting Research (IJEBAR)

Peer Reviewed - International Journal

Vol-5, Issue-1, 2021 (IJEBAR)

E-ISSN: 2614-1280 P-ISSN 2622-4771

http://jurnal.stie-aas.ac.id/index.php/IJEBAR

As indicated by Informants number 2 and 3 that the third Successor, Ari Suwono, has needed of capacity to deal with the company. He has absences of energy and has less in charge of building up the partnership, he has less communication to the workers and isn't near the representatives. He is less regarded and does not acknowledge to the company his friend. Furthermore, he isn't focal point of things to come sustainability of the company (Batik Semar company)

\section{Conclusion}

Creator masterminded the progression in PT. Danliris from the soonest beginning stage. It incorporated the confident of successors seen and overhauled from their character attempting to their formal guidance. The tutoring stage and training configuration are progressed nicely, typically, and sorted out to make an able successor for the headway of the organization. Progression procedure has been done effectively. Successors are moreover wanted to have a tolerable relationship with all parts of the organization. They moreover arranged to be exceedingly respected by the delegates by esteeming the antecedent and focus to the future sensibility of the organization.

PT. Batik Semar; The founders did not make readiness of succession by any means. They didn't hold mentoring process which likewise implies that there does not have any succession. The generation over age was finished by just indicating the one they think sufficiently reasonable to lead the company. The pointing was just turned into a custom. All activities and operating are finished and dealt with by the founder as the executive. Which make Batik Semar is less creating in light of the fact that successor has less in charge of things to come business sustainability.

\section{REFERENCES}

1992. Succession experience of the next generation. Family Business Review 5 (3):283-307.

[1] Adedayo, O. S., O. J. Olanipekun, and O. Ojo. 2016. Planning for succession and firm's sustainability: Evidence from family owned businesses in Lagos and Ogun States, Nigeria. Issues in Business Management and Economics 14 (6):63-69.

[2] Ahrens, J.-P., A. Landmann, and M. Woywode. 2015. Gender preferences in the CEO successions of family firms: Family characteristics and human capital of the successor. Journal of Family Business Strategy 6:86-103.

[3] Aronoff, C. E., S. McClure, and J. Ward. 2011. Business Succession: The Final Test of Greatness. 2nd ed. USA: Palgrave Macmillan.

[4] Barach, J., and J. Gantisky. 1995. Successful succession in family business. Family Business Review 8 (2):131-155.

[5] Baur, M. 2014. Successors and the Family Business: Novel Propositions and a New Guiding Model for Effective Succession. The Journal of American Academy of Business 19 (2):133138.

[6] Beckhard, R., and G. Dyer. 1983. Managing continuity in the family-owned business. Organizational Dynamics 12 (1):5-12. 
[7] Boyd, B., S. Royer, R. Pei, and X. Zhang. 2015. Knowledge transfer in family business successions: Implications of knowledge types and transaction atmospheres. Journal of Family Business Management 5 (1):17-37.

[8] Carlock, R., and J. L. Ward. 2001. Strategic Planning For The Family Business: Parallel Planning To Unify The Family And Business. New York: Palgrave Macmillan.

[9] Carsrud, A. L. 1994. Meanderings of a resurrected psychologist, or lessons learned in creating a family business program. Entrepreneurship Theory and Practice 19 (1):39-48.

[10] Chirico, F. 2007. The accumulation process of knowledge in family firms. Electronic Journal of Family Business Studies 1 (1):62-90.

[11] Chrisman, J. J., P. Sharma, and T. R. Yoder. 2009. Guiding family business through the succession process: a step by step guide for CPA advisors. The CPA Journal:48-51.

[12] Danco, L. 1982. Beyond Survival: A Guide for The Business Owner and His Family. Cleveland, $\mathrm{OH}:$ University Press.

[13] European Family Businesses. Definition of Famil Business 2016 [cited. Available from http://www.europeanfamilybusinesses.eu/family-businesses/definition.

[14] Fenn, D. 1994. Are your kids good enough to run your business. INC, 36-48.

[15] Ghee, W. Y., M. D. B. Ibrahim, and H. Abdul-Halim. 2015. Family business succession planning: Unleashing the key factors of business performance. Asian Academy of Management Journal 20 (2):103-126.

[16] Handler, W. 1990. Succession in family firms: a mutual role adjustment between entrepreneur and next-generation family members. Entrepreneurship Theory and Practice 15 (Auntumn):37-51.

[17] Handler, W. C. 1989. Methodological Issues And Consideration In Studying Family Business. Family Business Review 2 (3):257-276.

[18] Khorlina, M. M., and R. H. Mustamu. 2015. Analisis Proses Perencanaan Suksesi Pada Perusahaan Yang Bergerak Di Bidang Transportasi. Agora 3 (1):716-724.

[19] Lumintan, S. R., and R. H. Mustamu. 2015. Analisis Proses Suksesi Pada Perusahaan Produk Kecantikan. Agora 1 (1):97-104.

[20] Mandl, I. 2004. Business Transfers and Succession in Austria. In ISBE Research and Policy Conference. Teesside University.

[21] Miller, D., L. Steier, and I. Breton-Miller. 2003. Lost in time: intergenerational succession, change, and failure in family business. Journal of Business Venturing 18 (4):513-531.

[22] Miller, M., I. Le Breton-Miller, and B. Scholnick. 2008. Stewaardship and stagnation: An Empirical comparison of family and non-family business. Journal of Management Studies 45 (1):51-78. 
International Journal of Economics, Business and Accounting Research (IJEBAR)

Peer Reviewed - International Journal

Vol-5, Issue-1, 2021 (IJEBAR)

E-ISSN: 2614-1280 P-ISSN 2622-4771

http://jurnal.stie-aas.ac.id/index.php/IJEBAR

[23] Morris, M. H., R. W. William, and D. Nel. 1996. Factors influencing family business succession. International Journal of Entrepreneurial Behaviour \& Research 2 (3):68-81.

[24] Poza, E. J. 2010. Family Business. 3rd ed. USA: Cangage Learning Academic.

[25] Rothwell, W. J. 2001. Effective succession planning: Leadership continuity and building talent from within. New York: American Management Association.

[26] Sales, M. J. 1990. Succession planning in the family business. Small Business Reports 15 (2):31.

[27] Sharma, P., J. J. Chrisman, A. L. Pablo, and J. H. Chua. 2001. Determinants of initial satisfaction with the succession process in family firms: a conceptual model. Entrepreneurship Theory and Practice 25 (3):17-35.

[28] Singhry, H. B. 2010. An examination of management succession on the sustainability of family businesses in Nigeria: Problems and alternative solutions. In 2nd Annual International Conference on Business and Public Policy, 77-89.

[29] Susanto, A. B. 2007. Corporate social responsibility. Jakarta: The Jakarta Consulting Group.

[30] Tirdasari, N. L., and W. Dhewanto. 2012. Family business succession in Indonesia: A Study of Hospitality Industry. Procedia-Social and Behavioral Sciences 57:69-74.

[31] Ward, J. L. 2011. Keeping the Family Business Healthy: How to Plan for Continuing Growth, Profitability, and Family Leadership. New York: Palgrave Macmilalan. 